\title{
40. Neurosurgical Experiences under Total Circulatory Arrest with Profound Hypothermia using Extracorporeal Circulation
}

\author{
Hisao Manabe, Kenzo Hatsuoka, Tohru Uozumi, Tsuyoshi Fujita \\ Takeshi Ueda, Mitsumasa KanoH, Tsukasa Kishida, Kazuyasu NaKaO \\ and Kazuhiko NonaKa \\ First Department of Surgery, Osaka University Medical School \\ Dennosuke JinnaI, Heitaro Mogami, Kiyoo Kamikawa \\ Second Department of Surgery, Osaka University Medical School \\ Yutaka ONCHI \\ Department of Anesthesia, Osaka University Medical School \\ Masao MiYazaKI \\ Department of Anesthesia, Kyoto Prefectural University of Medicine
}

In the surgical department of Osaka University, four cases of neurosugical patients were treated under total circulatory arrest with profound hypothermia using extracorporeal circulation from July 1965 to June 1966. Two of the cases with highly vascularized gross meningiomas were operated with an open-chest technique, and the other two cases with an aneurysm and an arterio-venous malformation respetcively with a closed-chest technique.

Case K.T. was cooled to $30^{\circ} \mathrm{C}$ rectally on a cooling blanket and then to about $15^{\circ} \mathrm{C}$ with perfusion. Two venous canulas were inserted into the superior and inferior caval veins through the right atrium, and another in the left ventricle to decompress the left side of the heart. An arterial canula was placed in the femoral artery. The perfusion was first done under the flow rate of $2.01 / \mathrm{m}^{2} / \mathrm{min}$. and then about $0.51 / \mathrm{m}^{2} / \mathrm{min}$. after the rectaltempe rature reached about $15^{\circ} \mathrm{C}$. The tumour was resected piece by piece carefully and totally extirpated under the low flow perfusion and total circulatory arrest. But a massive and almost uncontrollable bleeding, mainly from the meningeal attachment to the falx cerebri, occurred after the perfusion was reopened, partly because of the insufficient electrocoagulation and clipping and partly the fibrinolytic phenomenon. The bleeding was controled about four hours after the blood was neutralized with protamine. Postoperatively she was semicomatous with severe thrombocpenia and hemorrhagic diathesis. She died on the 21 st postoperative day. Death was believed due to the intracranial bleeding but an autopsy was not done.

In Case Y.S. two venous canulas were inserted into the inferior caval vein through each external iliac vein, one of which into the right attrium and the other in the middle of the inferior caval vein, and an arterial one in the external iliac artery. After the surface cooling the patient was perfused under a flow rate of 
Table 1.

\begin{tabular}{|c|c|c|c|c|c|c|}
\hline Case Sex Age & Diagnosis & Operation & $\begin{array}{c}\text { Opern- on } \\
\text { Closed- } \\
\text { Chest }\end{array}$ & $\begin{array}{l}\text { Perfusion } \\
\text { Time } \\
\text { (Min.) }\end{array}$ & $\begin{array}{l}\text { The Lowest } \\
\text { Temperature } \\
\left({ }^{\circ} \mathrm{C}\right)\end{array}$ & $\begin{array}{c}\text { Total } \\
\text { Circulatory } \\
\text { Arrest } \\
\text { (Min.) }\end{array}$ \\
\hline S.K. f. 36 & $\begin{array}{l}\text { falx- } \\
\text { meningioma }\end{array}$ & extirp. & open & 211 & $\begin{array}{l}\text { esophagus } \\
12.0 \\
\text { rectum } \\
14.0\end{array}$ & 20 \\
\hline K.T. f. 37 & $\begin{array}{l}\text { falx- } \\
\text { meningioma }\end{array}$ & extirp. & open & 241 & $\begin{array}{l}\text { esophagus } \\
12.0 \\
\text { rectum } \\
15.0\end{array}$ & 55 \\
\hline S. f. 32 & $\begin{array}{l}\text { aneurysm } \\
\text { of } 1 . \mathrm{mid} \text {. } \\
\text { cereb. art. }\end{array}$ & ligation & closed & 177 & $\begin{array}{l}\text { esophague } \\
10.0 \\
\text { rectum } \\
12.0\end{array}$ & 7 \\
\hline H.N. f. 23 & $\begin{array}{l}\mathrm{A}-\mathrm{V}- \\
\text { malfoma. } \\
\text { of } 1 . \text { cereb. } \\
\text { hemisph. }\end{array}$ & extirp. & closed & 160 & $\begin{array}{l}\text { esophague } \\
9.0 \\
\text { rectum } \\
18.0\end{array}$ & 6 \\
\hline
\end{tabular}

$1.61 / \mathrm{m}^{2} / \mathrm{min}$. and then a low flow rate after about $15^{\circ} \mathrm{C}$ rectally. The neck of the aneurysm was easily tied off during the circulatory arrest of 7 minutes. The postoperative course has been uneventful.

The extirpation of the vascular malformation of Case H.N. was easily done with a closed-chst technique. But it was a serious experience that pulmonary edema was observed directly after the perfusion was reopened. The patient was deeply comatous postoperativly and increased intracranial pressure and pulmonary edema were repeatedly observed. She died on the third postoperative day and an autopsy revealed marked edema and stasis in her lungs. The reasons for this pulmonary edema have been left unclarified but the overdistension of the left side of the heart due to the absence of decompressing canual in the left ventricle was suspected to be one of the factors. 